\title{
大断面プレキャストコンクリー TEMPERATURE HISTORY IN 人部材製造時の温度履歴特性 PRODUCTION OF MASS PRECAST CONCRETE ELEMENTS
}

\section{杉山 央一－１ 1 \\ 桝田佳寛 — $* 2$ \\ 岩井信彰——3 \\ 中川侑治—* $* 4$ \\ キーワード \\ プレキャストコンクリート, 部材厚, セメント水和熱, 加熱養生, 温度履歴}

Keywords :

Precast concrete, Section size of elements, Heat of cement hydration, Heat curing, Temperature history

\author{
Hisashi SUGIYAMA - *1 \\ Nobuaki IWAI $-* 3$
}

\begin{abstract}
Yoshihiro MASUDA $-* 2$
\end{abstract}
Yuji NAKAGAWA —* 4

Mass precast concrete elements for columns and beams have been developed in recent years to improve the quality of reinforced concrete structures and simplify their methods of construction. The object of this work was to study the temperature history of mass precast concrete elements in their production process. By heat curing from the outside and internal storage of the heat of cement hydration, the mass precast concrete elements showed different temperature history from the thin precast concrete elements for walls and floor slabs. The temperature history at the center of mass precast concrete elements was different from that at the surface of mass precast concrete elements. A larger section size of elements resulted in larger difference in temperature between the center and the surface of mass precast concrete elements.

\section{1.はじめに}

年々、 R C 造建築物は高層化・大型化の方向に進んでいる。また、 安定した品質を確保しつつ工期の短縮ならびに施工の合理化を図る ため、プレキャストコンクリート工法を採用するケースが增えてお り、高層・大型建築物を建設する際にも導入されている。高層・大 型建築物に用いられる柱・梁など断面寸法の大きなプレキャストコ ンクリート部材では製造過程における外部からの加熱のみならず、 セメント水和熱の蓄積による内部での温度上昇も作用するため、断 面寸法の比較的小さな壁・㦿などのプレキャストコンクリート部材 とは異なった温度履歴を示すことが考えられる。さらに、この特異 な温度履歴が強度特性に大きな影響を及ぼすことが予想される。

また、調合計画および品質管理に関しても、断面寸法の比較的小 さなプレキャストコンクリート部材に用いられてきた従来の方法を、 断面寸法の大きなプレキャストコンクリート部材にそのまま適用で きるかどうかについては不明である。一般にプレキャストコンク リート部材に用いるコンクリートの調合を定める場合や品質管理を 行う場合には、プレキャストコンクリート部材と同一バッチから採 取したコンクリートをプレキャストコンクリート部材と同一の養生 条件で養生した円柱供試体（以下、「部材養生供試体」と略記）の強 度試験結果を代用している。すなわち、同一の加熱楸生槽内で養生 したプレキャストコンクリート部材と円柱供試体は、同一の温度履 歴特性および同一の強度特性を示すという考えに基づいている。し かし、前記の理由から断面寸法の大きなプレキャストコンクリート 部材は、部材養生供試体とは異なる温度履歴特性および強度特性を 示すことが予想される。

\footnotetext{
*1 独立行政法人建築研究所材料研究グループ 主任研究員・工博 (テ305-0802 つくば市立原1)

*2 宇都宮大学工学部建設学科 教授・工博

*3 新新井組技術研究所 主任研究員

*4 東海與業俶技術開発部 副長
}

このような背景のもと、強度特性の検討に先立ち、本報告では温 度履歴特性を明らかにすることを目的とした。筆者らは、これまで に断面寸法の大きなプレキャストコンクリート模擬部材の製造実験

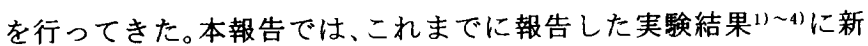
たな実験結果を加え、断面寸法、使用セメント、調合および加熱養 生条件がそれぞれ異なるプレキャストコンクリート部材の製造時に おける温度履歴特性を総括的に検討した。

\section{2. 実験概要}

\section{1 使用材料および調合}

セメントには表1に示す性質の各ポルトランドセメントを使用し た。なお、普通ポルトランドセメント $(\mathrm{N})$ としては、表 1 に示す $\mathrm{N} 1$ お よびN2を等量ずつ混合したものを使用した。細骨材には鬼怒川産川 砂 (最大寸法 $5 \mathrm{~mm}$ ，表乾密度 $2.58 \mathrm{~g} / \mathrm{cm}^{3}$, 吸水率 $2.07 \%$ ，粗粒率 2.88 ) を、粗骨材には岩瀬産砕石 (最大寸法 $20 \mathrm{~mm}$, 表乾密度 $2.66 \mathrm{~g} / \mathrm{cm}^{3}$, 吸 水率 $0.68 \%$ ，粗粒率 6.64 ，実積率 $59.8 \%$ ) 使用した。コンクリート の調合を表 2 に示す。

\section{2 試験体の形状および寸法}

図1に示すように、断面寸法が異なる 3 種類のプレキャストコンク リート模擬部材試験体（以下、「模擬部材」と略記）を作製した。模 擬部材 $\mathrm{A}$ は部材厚 $600 \mathrm{~mm}$ の柱部材を、模擬部材 B は部材厚 $400 \mathrm{~mm}$ の 梁部材を、模擬部材Cは部材厚 $200 \mathrm{~mm}$ の壁・床部材をそれぞれ模擬し ている。なお、模澵部材の断面における短辺方向の寸法を部材厚と定 義した。また、それぞれの模擬部材と同一バッチのコンクリートから 円柱供試体 $(\phi 100 \times 200 \mathrm{~mm})$ を作製した。

*1 Senior Research Engineer, Dept. of Building Materials and Components, Building Research Institute, Dr. Eng.

*2 Prof., Dept. of Architecture and Civil Engineering, Faculty of Engineering, Utsunomiya Univ., Dr. Eng.

*3 Senior Research Engineer, Technical Research Institute, Araigumi Co., Ltd.

*4 Deputy Head, Technical Development Dept., Tokai Kogyo Corporation 


\section{3 菱生条件}

加熱盖生としては、コンクリート打込み後に屋外で $2 \sim 3 \mathrm{~h}$ の前盖 生を行った後、加熱盖生槽（槽内湿度 $95 \%$ RH以上）において温度上 昇勾配 $20^{\circ} \mathrm{C} / \mathrm{h}$ 、最高温度継続時間 $3 \mathrm{~h}$ 、温度下降勾配 $10^{\circ} \mathrm{C} / \mathrm{h}$ 以下の 条件を計画した。加熱養生における目標最高温度 (以下、「加熱最高 温度」と略記）には $40 、 60$ および $80^{\circ} \mathrm{C} の 3$ 水準を設定した。また、 加熱を行わないコンクリート打込み直後からの屋外養生も計画した。 模擬部材は材齢3日に脱型し、その後は屋外での気中養生を行った。 また、円柱供試体は成型直後に封かん状態とし、それぞれの模擬部材 と同一の加熱養生槽内において同一条件の養生を行い、部材養生供試 体とした。

\section{4 模擬部材の種類}

模擬部材に用いるコンクリートの調合、模擬部材の形状および荃生 条件の組み合わせを表 3 に示す。表中で、記号の末尾にWを付した模 擬部材は冬期に製造したものであり、春期や秋期に製造した他の模擬 部材に比ベてコンクリートの打込み温度、前養生温度および脱型以後 の義生温度が低かった。このため、Wを付して他の模擬部材と区別した。

\section{5 温度測定}

図1に示す位置にC-C型熱電対を埋め込み、コンクリート打込み直 後から材齡3日までの模擬部材の温度を測定した。同様に、部材養生 供試体の中心部の温度を測定した。なお、模擬部材近傍の気温(蒸気 温度)を測定し、これを䨌囲気温度と定義した。

表1 使用セメントの物理的性質および化合物組成

\begin{tabular}{|c|c|c|c|c|c|c|c|c|c|}
\hline \multirow[t]{2}{*}{ 壾号 } & \multirow{2}{*}{$\begin{array}{l}\text { セxト } \\
\text { 種類 } \\
\end{array}$} & \multirow{2}{*}{$\begin{array}{c}\begin{array}{c}\text { 密度 } \\
\left(\mathrm{g} / \mathrm{cm}^{3}\right)\end{array} \\
\end{array}$} & \multirow{2}{*}{$\begin{array}{c}\text { 比表面積 } \\
\left(\mathrm{cm}^{2} / \mathrm{g}\right)\end{array}$} & \multicolumn{2}{|c|}{ 政結時間 (h-min) } & \multicolumn{4}{|c|}{ 化合物組成(\%) } \\
\hline & & & & 始発 & 終結 & $\mathrm{C}_{3} \mathrm{~S}$ & $\mathrm{C}_{2} \mathrm{~S}$ & $\mathrm{C}_{3} \mathrm{~A}$ & $\mathrm{C}_{4} \mathrm{AF}$ \\
\hline N1 & 普通 & 3.16 & 3330 & $2-15$ & $3-15$ & 53.7 & 20.9 & 8.6 & 8.8 \\
\hline N2 & 普通 & 3. 15 & 3250 & $2-25$ & $3-58$ & 52.1 & 22.1 & 9.5 & 8.2 \\
\hline $\bar{H}$ & 早強 & 3. 13 & 4420 & $2-01$ & $2-53$ & 64.3 & 10.6 & 8.2 & 8.2 \\
\hline$L$ & 低熱 & 3. 20 & 4190 & $2-25$ & $3-25$ & 34.5 & 46.9 & 2.8 & 8.8 \\
\hline
\end{tabular}

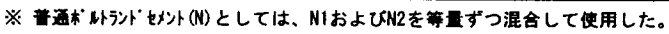

\begin{tabular}{|c|c|c|c|c|c|c|c|c|c|c|c|}
\hline \multirow[t]{2}{*}{ 町号 } & \multirow{2}{*}{$\begin{array}{l}\text { 使用 } \\
\text { せシト } \\
\text { 種類 }\end{array}$} & \multirow{2}{*}{$\begin{array}{l}W / c \\
(x)\end{array}$} & \multirow{2}{*}{ 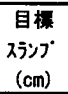 } & \multirow{2}{*}{$\begin{array}{c}\text { 目摆 } \\
\text { 空文量 } \\
(\%)\end{array}$} & \multirow{2}{*}{$\begin{array}{l}s / a \\
(y)\end{array}$} & \multicolumn{4}{|c|}{$\begin{array}{l}\text { 単位量 } \\
\left(\mathrm{kg} / \mathrm{m}^{3}\right)\end{array}$} & \multicolumn{2}{|c|}{ 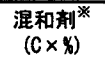 } \\
\hline & & & & & & W & $c$ & $S$ & $G$ & Ad1 & Ad2 \\
\hline N33 & 蒴通 & 33.3 & 21.0 & 1.0 & 47.1 & 160 & 480 & 824 & 954 & 1.0 & 0.1 \\
\hline $\mathrm{N} 40$ & 著通 & 40.0 & 18. 0 & 1.0 & 48.1 & 160 & 400 & 872 & 972 & 1.0 & 0.1 \\
\hline N50 & 兽通 & 50.0 & 12.0 & 1.0 & 46.6 & 160 & 320 & 877 & 1035 & 1.1 & 0.1 \\
\hline $\mathrm{H} 33$ & 早强 & 33.3 & 21.0 & 1.0 & 47.0 & 160 & 480 & 820 & 954 & 0.9 & 0.1 \\
\hline $\mathrm{H} 4 \mathrm{O}$ & 早強 & 40.0 & 18.0 & 1.0 & 48.1 & 160 & 400 & 871 & 970 & 0.9 & 0.1 \\
\hline H5O & 早強 & 50.0 & 12.0 & 1.0 & 46.6 & 160 & 320 & 875 & 1034 & 0.9 & 0.1 \\
\hline L33 & 低熱 & 33.3 & 21.0 & 1.0 & 47.2 & 160 & 480 & 828 & 954 & 0.9 & 0.1 \\
\hline L40 & 低熱 & 40.0 & 18.0 & 1.0 & 48. 3 & 160 & 400 & 878 & 970 & 0.9 & 0.1 \\
\hline L50 & 低鶖 & 50.0 & 12.0 & 1.0 & 46.8 & 160 & 320 & 881 & 1034 & 0.9 & 0.1 \\
\hline
\end{tabular}

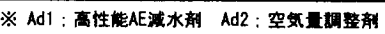

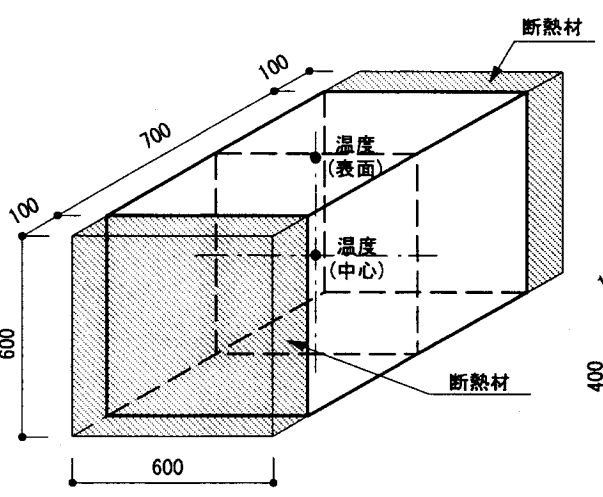

模擬部材 $A$

※ 表面部の温度は、模擬部材上面より深さ $10 \mathrm{~mm}$ の位置にC-C型熱電対を埋め込んで測定した。

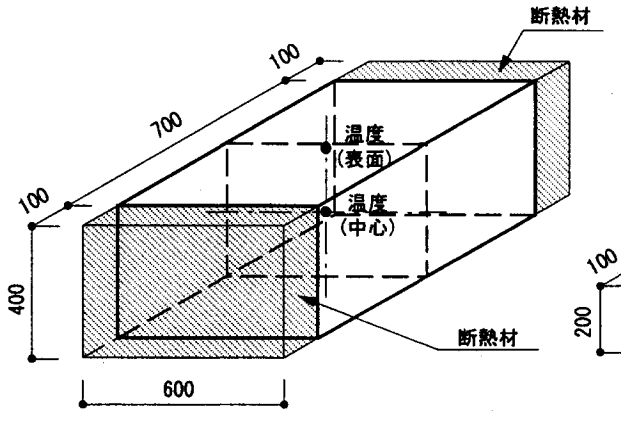

模擬部材 $\mathrm{B}$

\section{3. 実験結果および考察}

模擬部材の中心部、表面部および部材養生供試体の温度測定結果を 表3に示す。それぞれの温度測定部位において履歴した最高温度を履 歴最高温度と定義した。また、温度上昇開始から最初の温度ピークに 到達するまでの温度測定データをもとに線形回㷌計算を行い、算出さ れた勾配值を温度上昇勾配と定義した。なお、温度勾配 $2^{\circ} \mathrm{C} / \mathrm{h}$ 以上の 温度上昇が認められた時点を温度上昇の開始時期とした。

\section{1 部材厚の違いによる温度履歴の比較}

部材厚別による模擬部材の温度履歴を図2に示す。なお、図中には 部材養生供試体の温度履歷も示す。部材養生供試体では、雰囲気温度

表3 模擬部村の種類および温度測定結果

\begin{tabular}{|c|c|c|c|c|c|c|c|c|c|c|c|}
\hline \multirow{3}{*}{ 涀号 } & \multirow{3}{*}{ 㽗合 } & \multirow{3}{*}{ 形状 } & \multicolumn{2}{|c|}{ 衰生方法 } & \multicolumn{7}{|c|}{ 温度测定結果 } \\
\hline & & & \multirow{2}{*}{ 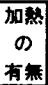 } & \multirow{2}{*}{$\begin{array}{c}\text { 加䓡最高 } \\
\text { 温度圤 } \\
\left({ }^{\circ} \mathrm{C}\right)\end{array}$} & \multirow{2}{*}{\begin{tabular}{|c|} 
打込み \\
温度 \\
$\left({ }^{\circ} \mathrm{C}\right)$
\end{tabular}} & \multicolumn{3}{|c|}{ 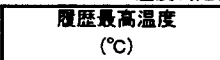 } & \multicolumn{3}{|c|}{$\begin{array}{c}\text { 温度上算勾眍 } \\
\left({ }^{\circ} \mathrm{C} / \mathrm{h}\right)\end{array}$} \\
\hline & & & & & & 中心部 & 表面部 & 供侙体* & 中心部 & 袁面部 & 供试 \\
\hline$\sqrt{333-A-60 W}$ & 33 & $\bar{A}$ & 有 & 60 & 17.0 & 72.7 & 51.2 & 68.2 & 5.1 & 8.0 & 14.6 \\
\hline $40-A-80 W$ & 40 & A & 有 & 80 & 13.5 & 79.7 & 5.1 & 2.4 & 6.0 & 6 & 3. 9 \\
\hline $40-A-60$ W & 40 & A & 有 & 60 & 13.0 & 64.5 & 48.5 & 5.8 & 4. 1 & 6.7 & 2.6 \\
\hline $40-A-40 W$ & 40 & A & 有 & 40 & 13.0 & 50.9 & 42.0 & 44.7 & 1.9 & 3.5 & 0.5 \\
\hline $450-A-60 \mathrm{WW}$ & N50 & A & 有 & 60 & 14.0 & .8 & 49. 2 & 2.1 & 2.6 & 6.9 & 6 \\
\hline $33-A-80$ & N33 & A & 有 & 80 & 26.0 & 4 & 84.4 & .2 & 7.0 & 5 & 7 \\
\hline$A-00$ & N33 & A & 無 & - & 25.0 & 59.1 & 3.5 & 3.7 & 2.4 & .9 & .7 \\
\hline 0 & N40 & A & 有 & 60 & 24.0 & 8 & 59.1 & 6.7 & 5.5 & 6.6 & 15.5 \\
\hline & $N 40$ & A & 無 & - & 24.0 & 6 & 41.7 & 3.9 & 2.1 & 3 & 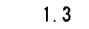 \\
\hline & N40 & B & 有 & 60 & 24.0 & & 61.8 & 7.8 & 4. 8 & 1 & 15. 9 \\
\hline $8-00$ & N40 & B & 無 & - & 5.0 & 4 & 8 & 3 & 3. 5 & 1 & 1.7 \\
\hline 0 & N40 & C & 有 & 60 & 4.0 & .1 & 66.3 & 7. 8 & 5.5 & 7.0 & 15. 9 \\
\hline & & $c$ & 無 & - & 5.0 & .8 & 54. 1 & 8. 3 & 3.0 & 3.0 & 9 \\
\hline$-A-00$ & 0 & A & 慜 & - & 4.0 & 4.1 & 34.8 & 1.2 & 1.0 & 0.8 & 0.7 \\
\hline $33-A-80$ & $\overline{\mathrm{H} 3}$ & $\bar{A}$ & 有 & 80 & 18.5 & 9 & 80.9 & 2.1 & 8.0 & 7.7 & $\overline{15 .}$ \\
\hline 30 & & A & 有 & 60 & 0.0 & 6 & 66.1 & 75.3 & 8.8 & 8. 1 & 17.2 \\
\hline & & A & 無 & - & 0.5 & 3 & 50.2 & 4.0 & 3.1 & 2.2 & 0. \\
\hline & $\mathrm{H} 4 \mathrm{O}$ & A & 有 & 80 & 18.5 & 5 & 73.0 & 81.5 & 7.0 & 7.2 & 12. \\
\hline & $\mathrm{H} 4 \mathrm{O}$ & A & 有 & 60 & 20.0 & 8 & 62.9 & 70.6 & 6. 3 & 8. 5 & 14. \\
\hline & $\mathrm{H}$ & A & 有 & 40 & 23.0 & 2 & 54.2 & 48.6 & 4.0 & 3.1 & 11.3 \\
\hline & $\mathrm{H} 40$ & A & 無 & - & 9.5 & 5 & 37.5 & 5. 3 & 1.9 & 1.7 & 0.7 \\
\hline & $\mathrm{H}$ & 8 & 有 & 60 & 1.0 & 5 & 64.4 & 5 & 6.3 & 4 & 3. \\
\hline & $\mathrm{H} 4$ & C & 有 & 60 & 19.0 & 8 & 69.4 & 2 & 6.5 & 7 & 12. \\
\hline & $\mathrm{H}$ & C & 慗 & - & 19.0 & 40.7 & 39.5 & 19.5 & 1.7 & 7 & 0.5 \\
\hline 0 & $\mathrm{H}$ & A & 有 & 60 & 19.0 & 69.9 & 61.1 & 6.6 & 4.5 & 8.0 & 12.5 \\
\hline 0 & H50 & A & 策 & - & 21.0 & .9 & 39. 5 & 4. 1 & 8 & 1.5 & 0.6 \\
\hline$A-80$ & L33 & A & 有 & 80 & 17.5 & 72.5 & 69.8 & 5.6 & 4.6 & 7.0 & 10.3 \\
\hline 0 & L3 & A & 有 & 60 & 18.5 & 67.3 & 59.0 & 68.2 & 5.3 & 7.9 & 13.1 \\
\hline-00 & L & A & 無 & - & 21.5 & 47.9 & 38.7 & 7.3 & 1.5 & 1.2 & 0.0 \\
\hline & L4 & A & 有 & 80 & 18.5 & 70.3 & 69.9 & 82. 2 & 5.2 & 7.6 & 10.8 \\
\hline & LA & A & 有 & 60 & 17.5 & 60.2 & 58.0 & 65.8 & 4.4 & 7.8 & 12.4 \\
\hline & L4 & A & 有 & 40 & 22.5 & 52.0 & 42.1 & 45.3 & 2.9 & 3.4 & 11.2 \\
\hline & LA & A & 無 & - & 21.5 & 39.2 & 32.4 & 4. 3 & 1.2 & 0.7 & 0.0 \\
\hline & LC & B & 有 & 60 & 21.0 & 61.9 & 59.7 & 6.1 & 4. 6 & 7.4 & 13.3 \\
\hline & L4 & C & 有 & 60 & 18.5 & 57.1 & 57.6 & 7.0 & 5.4 & 5.5 & 13.7 \\
\hline & L4 & C & 筆 & - & 18.5 & 21.9 & 21.7 & 3. 5 & 0.2 & 0.4 & 0.0 \\
\hline & L5 & A & 有 & 60 & 18.0 & 54 & 56.5 & .8 & 3.7 & 7.5 & 12.7 \\
\hline-00 & $\angle 50$ & $A$ & 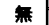 & - & 18.0 & 31.6 & 23. 8 & 18. 2 & 0.7 & 0.5 & 0.0 \\
\hline
\end{tabular}

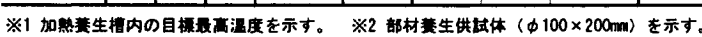



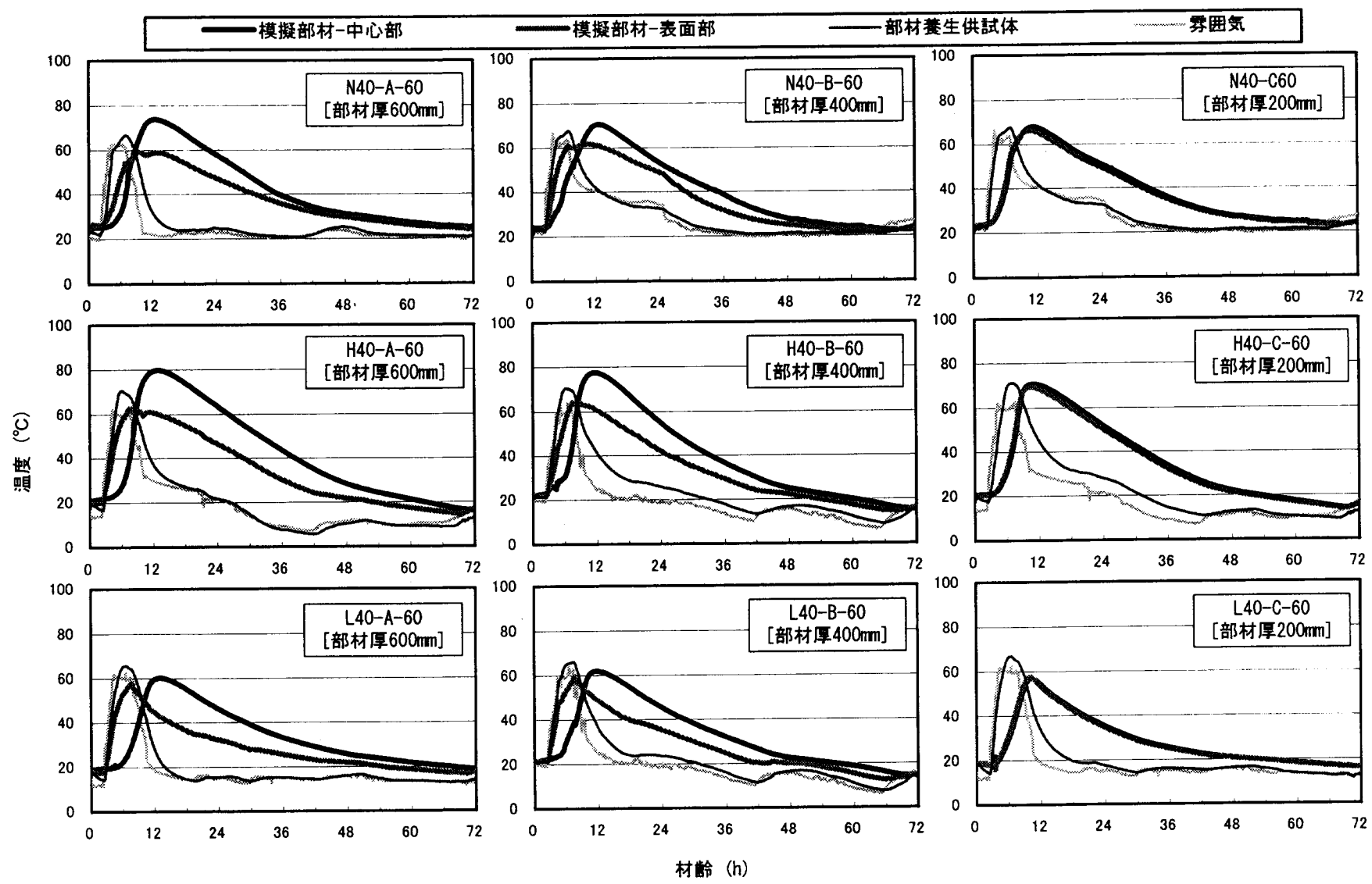

図2模擬部材の温度履歴（部材厚による比較）

と大差ない温度履歷が認められた。すなわち、加熱開始と同時に急激 な温度上昇が生じ、履歴最高温度は雲囲気中の最高温度を若干上回る が、加熱終了と同時に温度降下が始まった。他方、模擬部材の温度履 歴は、需囲気温度や部材養生供試体の温度履歴とは大きく異なるもの であった。すなわち、部材養生供試体に比べて温度上昇勾配および加 熱終了後の温度下降勾配が緩やかであった。

図 2 において模擬部材の中心部と表面部の温度履歴を比較する と、部材厚が大きいほど中心部と表面部の温度履歷の差異が大きい ことがわかる。模擬部材Cでは中心部と表面部の温度履歷がほぼ等 しい。これに対して、模擬部材 AおよびBでは中心部と表面部の温 度履歴の差異が大きく、中心部では表面部より $2 \sim 4 \mathrm{~h}$ 遅れて緩やか に温度上昇を開始するが、温度上昇量が大きく、12h以降では表面 部より高温となった。また、履歷最高温度についても、中心部では 表面部よりも高い値を示した。

H4O における模擬部材の部材厚と温度履歴要因の関係を図 3 に示 す。中心部では、部材厚が大きくなるほど履歷最高温度および温度上 昇量が増加する。これは、部材厚が大きくなるほど部材内部のセメン 卜水和熱が外部に放出されず、内部に蓄積される傾向が著しくなるこ とに起因している。部材厚 $200 \sim 600 \mathrm{~mm}$ の範囲において、部材厚が $100 \mathrm{~mm}$ 大きいことによる中心部の履歷最高温度の上昇量は、N40で約 $1.4^{\circ} \mathrm{C} 、 \mathrm{H} 40$ で約 $2.3^{\circ} \mathrm{C} 、 \mathrm{~L} 40$ で約 $0.8^{\circ} \mathrm{C}$ であった。他方、表面部では 部材厚が大きくなるほど履歷最高温度および温度上昇量が堿少する傾 向が認められた。これは、部材厚が大きいほど部材の単位長さあたり の熱容量も大きくなり、加熱養生により表面部に加えられた熱がより 多く内部に伝導することに起因している。
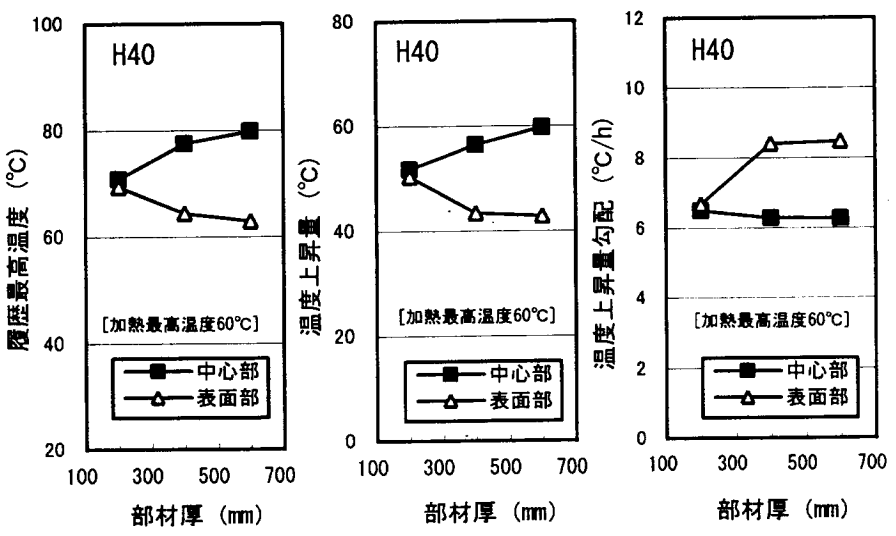

図3部材厚と温度履歴要因の関係 $(\mathrm{H} 40)$
[中心部一供弑体]

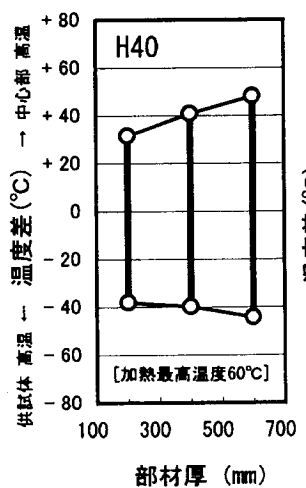

[表面部一供軾体]

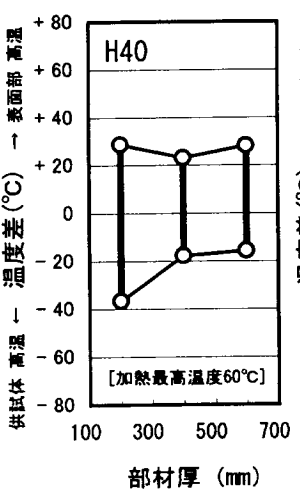

[中心部一表面部]

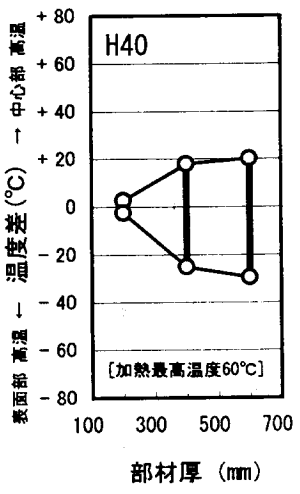

図4部材厚と部位間に生じた温度差の範囲（H40） 

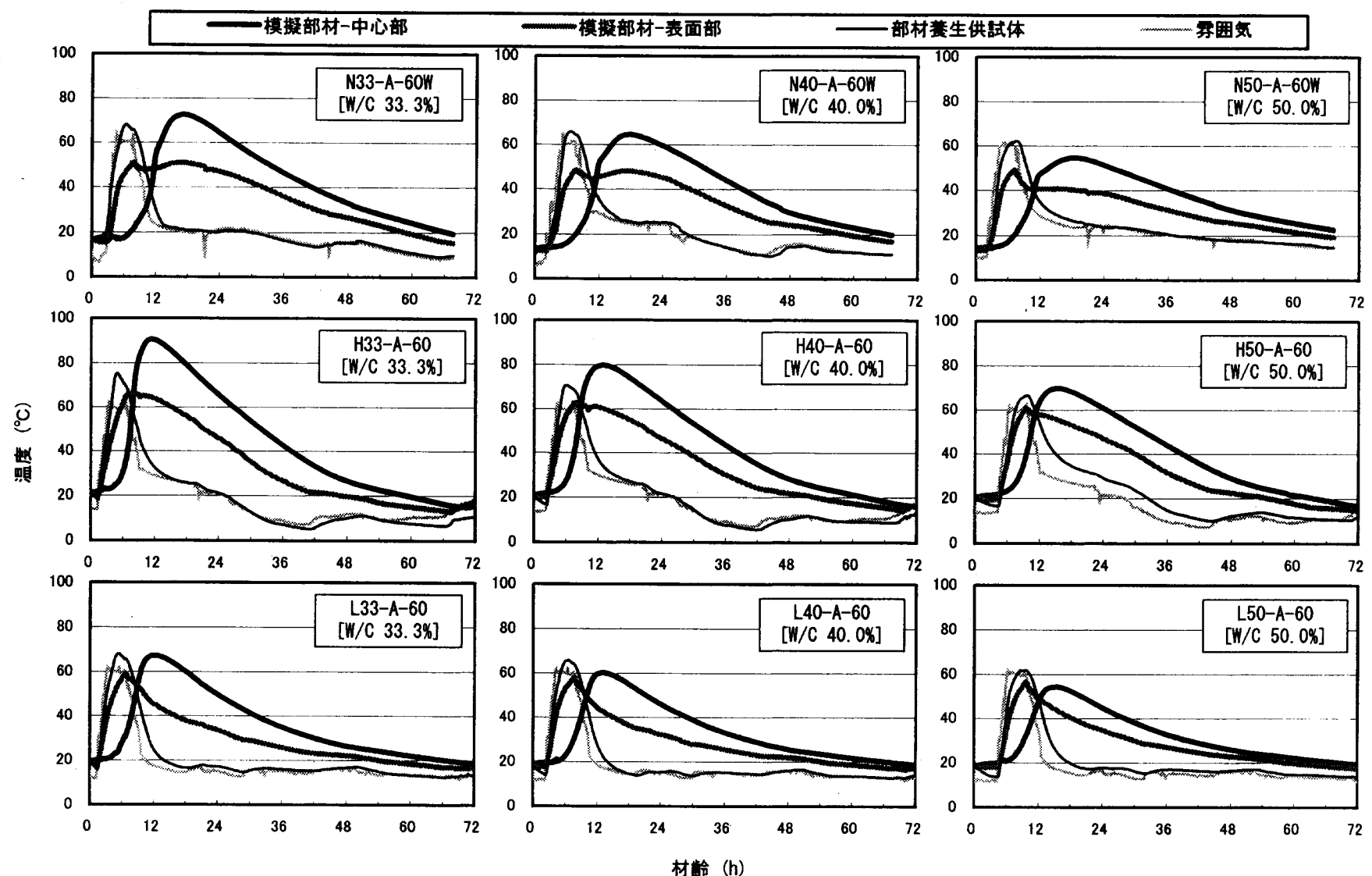

図5模擬部材の温度履歴（水セメント比による比較）

模擬部材中心部、表面部および部材垗生供試体の温度を同一測定時 刻において比較し、それぞれの間に生じた温度差を部材厚との関係か ら検討した。H40におけるそれぞれの部位間に生じた温度差の範囲を 部材厚との関俰から検討したものを図4に示す。図中で十の符号は前 者の温度の方が高い場合における両者の温度差を、また、一の符号は 後者の温度の方が高い場合におけす両者の温度差をそれぞれ示してい る。模擬部材中心部と部材荃生供試体の間には大きな温度差が認めら れ、部材厚が大きくなるほど両者には大きな温度差が生じる。また、 部材厚が大きくなるほど模擬部材中心部と表面部の温度差も大きくな り、温度差の範囲は部材厚 $200 \mathrm{~mm}$ で $-2.5 \sim+2.7^{\circ} \mathrm{C}$ であるのに対し て、部材厚 $600 \mathrm{~mm}$ では $-29.6 \sim+20.3^{\circ} \mathrm{C}$ であった。

以上のような断面寸法の大きな模擬部材の特異な温度履歴特性は、 外部からの加熱に加えて、部材厚が大きいことによるセメント水和熱 の内部蓄積に起因している。すなわち、表面部の温度履歴は雾囲気温 度に大きな影響を受け、中心部の温度履歴はセメント水和熱に大きな 影響を受ける。このため、同一部材における中心部と表面部の温度㠅 歴の差異は、セメント水和熱量の大きな早強セメントを用いた模擬部 材において大きく、反対に、セメント水和熱量の小さな低熱セメント を用いた模擬部材においては比較的小さい。

\section{2 調合の遗いによる温度履歴の比較}

水セメント比別による模擬部材および部材荃生供試体の温度履歴を 図5に示す。模擬部材表面部および部材養生供試体の温度履歴には、 調合の違いによる大きな差異は認められなかった。しかし、模擬部材 中心部の温度衤歴には調合の違いによる大きな差異が認められ、水セ
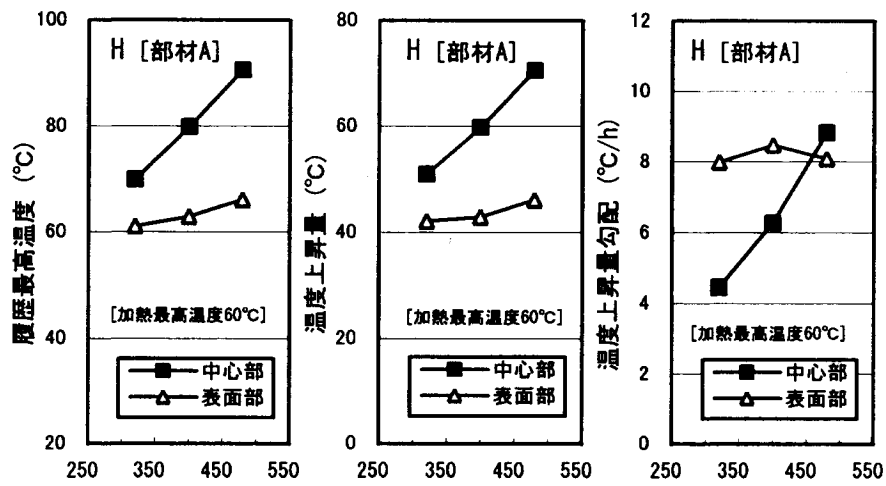

単位セメント青 $\left(\mathrm{kg} / \mathrm{m}^{3}\right)$ 単位セメント量 $\left(\mathrm{kg} / \mathrm{m}^{3}\right)$ 単位セメント旦 $\left(\mathrm{kg} / \mathrm{m}^{3}\right)$ 図6 単位セメント量と温度履歴要因の関係 $(H-$ 部材 $A)$

[中心部一供弑体] [表面部一供䳝体] [中心部一表面部]
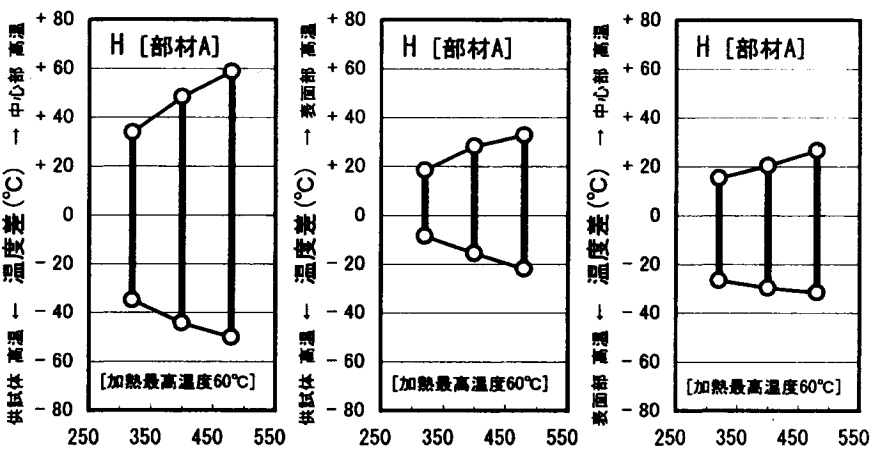

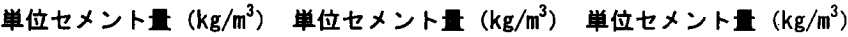
図7単位セメント量と部位間に生じた温度差の簕囲（H-部材 $A)$ 

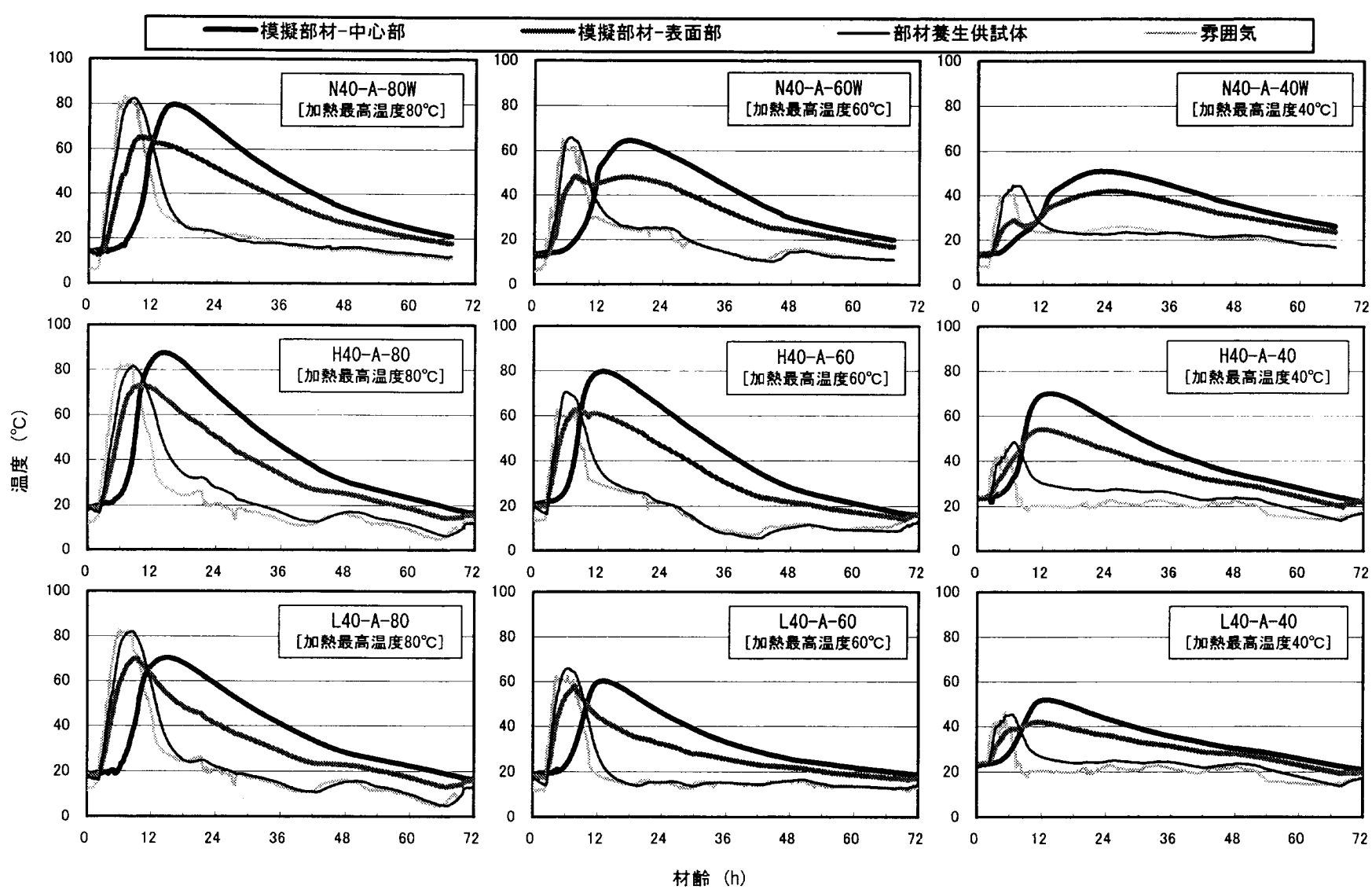

図8模擬部材の温度履歴（加熱養生条件による比較）

メント比が小さい模擬部材ほど、すなわち単位セメント量が多い模擬 部材ほど中心部の履歴温度が高かった。特に、この傾向は早強セメン トを用いた模擬部材において顕著であった。

早強セメントを用いた模擬部材Aにおける単位セメント量と温度履 歴要因の関倸を図6に示す。表面部では、単位セメント量が増加して も履歷最高温度、温度上昇量および温度上昇勾配に大きな差異が認め られない。これに対して、中心部では単位セメント量が多くなるほど 履歷最高温度、温度上昇量および温度上昇勾配が著しく増加すること がわかる。単位セメント量 $320 \sim 480 \mathrm{~kg} / \mathrm{m}^{3}$ の範囲において、単位セ メント量が $10 \mathrm{~kg} / \mathrm{m}^{3}$ 増加することによる模擬部材 $\mathrm{A} の$ 履歴最高温度の 上昇量は、普通セメントを用いた場合では表面部で約 $0.1^{\circ} \mathrm{C} 、$ 中心部 で約 $1.1^{\circ} \mathrm{C}$ 、早強セメントを用いた場合では表面部で約 $0.3^{\circ} \mathrm{C} 、$ 中心 部で約 $1.3^{\circ} \mathrm{C}$ 、低熱セメントを用いた場合では表面部で約 $0.2^{\circ} \mathrm{C} 、$ 中 心部で約 $0.8^{\circ} \mathrm{C}$ であった。また、履歴最高温度および温度上昇量の中 心部と表面部による差は、単位セメント量が多くなるほど増加するこ とがわかる。

早強セメントを用いた模擬部材Aにおけるそれぞれの部位間に生じ た温度差の範囲を単位セメント量との関係から検討したものを図7に 示す。模擬部材中心部と部材養生供試体の間には、単位セメント量が 多くなるほど大きな温度差が生じることがわかる。また、単位セメン 卜量が多くなるほど模擬部材中心部と表面部の温度差も大きくなり、 温度差の範囲は単位セメント量 $320 \mathrm{~kg} / \mathrm{m}^{3}$ で $-26.5 \sim+15.3^{\circ} \mathrm{C}$ あ゙あ

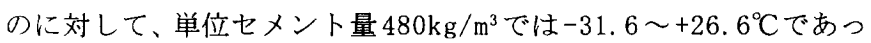
た。

\section{3 加熱養生条件の違いによる温度履歴の比較}

加熱最高温度別による模擬部材および部材盖生供試体の温度履歷を 図8に示す。加熱最高温度が高い模擬部材ほど中心部と表面部の履歷 温度は高くなった。H40の模擬部材Aの中心部では、いずれの加熱盖 生条件においても履歷最高温度が加熱最高温度を上回った。これに対

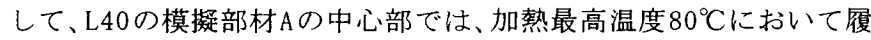
歴最高温度が加熱最高温度に達しなかった。また、N40、H40および

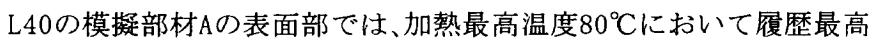
温度が加熱最高温度に達しなかった。加熱最高温度 $40 \sim 80^{\circ} \mathrm{C}$ の範囲 において、加熱最高温度が $10^{\circ} \mathrm{C}$ 高いことによる模擬部材 $\mathrm{A} の$ 履歷最高 温度の上昇量は、 $\mathrm{N} 40$ の場合では表面部で約 $5^{\circ} \mathrm{C} 、$ 中心部で約 $6{ }^{\circ} \mathrm{C} 、 \mathrm{H} 40$ の場合では表面部および中心部で約 $5^{\circ} \mathrm{C} 、 L 40$ の場合では表面部で約 $7^{\circ} \mathrm{C} 、$ 中心部で約 $5^{\circ} \mathrm{C}$ であった。

3.4 高強度プレキャストコンクリート部材および屋外養生プレキャ ストコンクリート部材の温度履歴

近年、コンクリートは高強度化への方向に進展しているが、今後プ レキャストコンクリート部材についても高強度化への進展が予想され る。そこで、加熱養生した高強度プレキャストコンクリート部材の温 度履歴特性について検討した。水セメント $33.3 \%$ 、加熱最高温度 80 ${ }^{\circ} \mathrm{C}$ における模擬部材 $\mathrm{A}$ の温度履歴を図 9 に示す。これらは、本実験の 範囲内で最も高い温度を履歷するための条件を備えたものである。中 心部の履歴最高温度は、N $33-\mathrm{A}-80$ では $97.4^{\circ} \mathrm{C} 、 \mathrm{H} 33-\mathrm{A}-80$ では 96.9

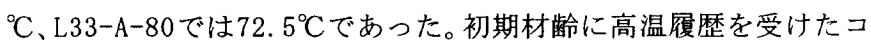
ンクリートの強度発現性には特異な傾向が認められ、特に初期材齢で 


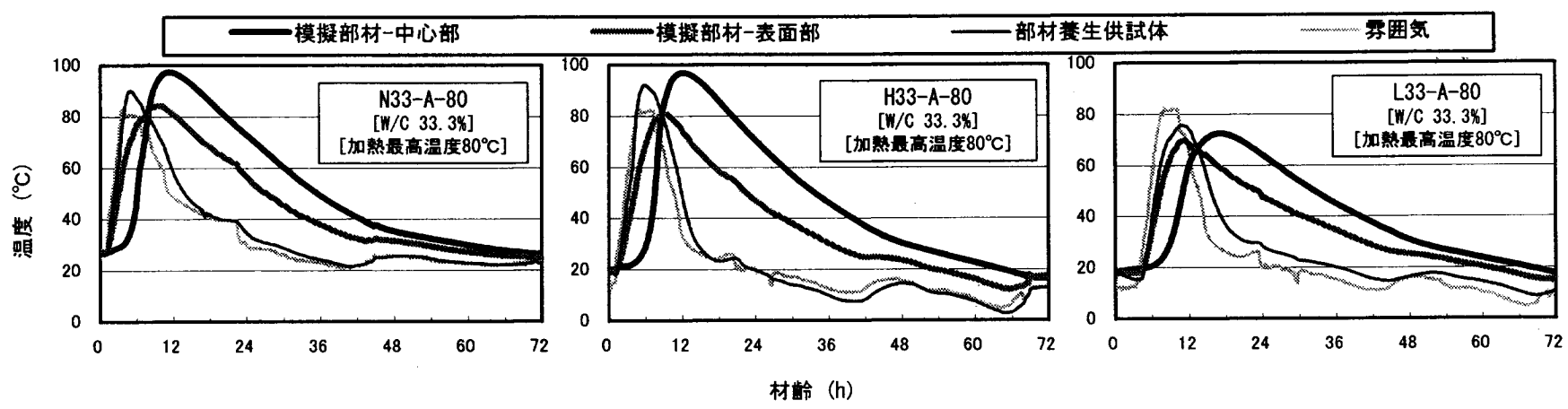

図9模擬部材の温度履歴（水セメント比 $33.3 \% ，$ 加熱最高温度 $80^{\circ} \mathrm{C}$ ）

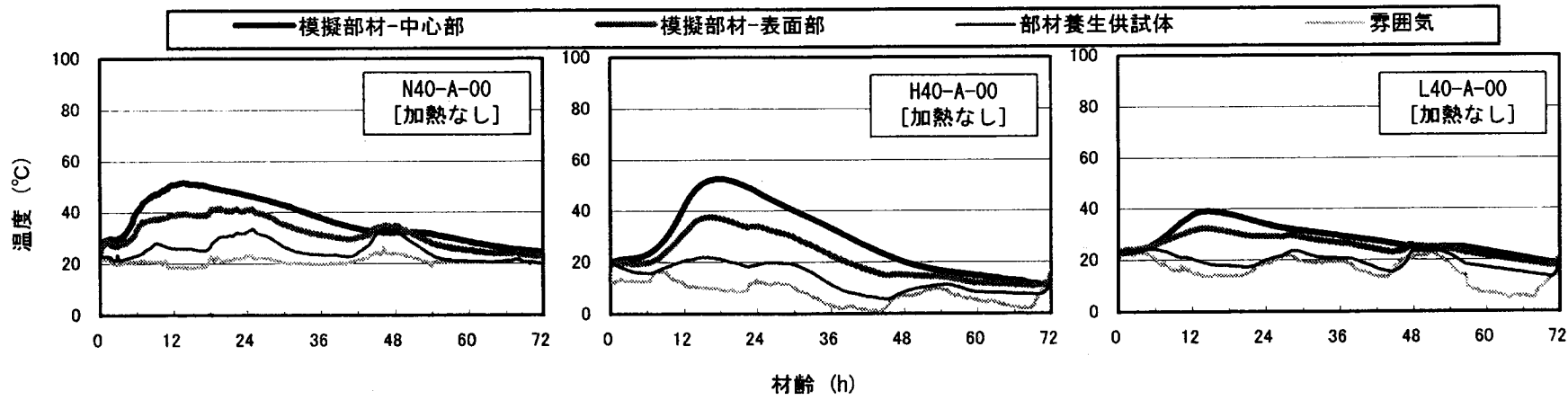

図10 模擬部材の温度履歴（加熱なし）

の $90^{\circ} \mathrm{C}$ 超える高温履歷はコンクリートの長期強度の増進性に大きな 影響を及ぼすことが報告されている5 従って、断面寸法が大きく、 高強度すなわち単位セメント量の多いプレキャストコンクリート部材 を加熱養生することにより製造する場合には、著しい高温履歷が強度 特性や耐久性に及ぼす影響を明らかにしておく必要がある。

他方、加熱養生することなく、コンクリート打込み直後から屋外羕 生した模擬部材 $\mathrm{A}$ の温度履歴を図 10 に示す。中心部の履歴最高温度 は、N40-A-00では $51.6^{\circ} \mathrm{C} 、 H 40-A-00$ では $52.5^{\circ} \mathrm{C} 、 L 40-\mathrm{A}-00$ では $39.2^{\circ} \mathrm{C}$ であった。外気温の高い夏期には履歴最高温度がさらに高くな り、断面寸法が大きなプレキャストコンクリートでは加熱養生するこ となく初期材㱓での強度発現が促進されると考えられる。

4. まとめ

1）部材養生供試体すなわち部材と同一の養生条件で養生した円柱供 試体では、雾囲気温度と大差ない温度履歷を示す。他方、断面寸 法の大きなプレキャストコンクリート部材では、雾囲気温度や部 材養生供試体とは大きく異なる温度履歷を示す。

2）断面寸法の大きなプレキャストコンクリート部材では、中心部と 表面部の温度履歴が異なり、部材厚が大きくなるほど中心部と表 面部の温度差は大きくなる。これは、表面部の温度履歷は外部か らの加熱すなわち雲囲気温度に大きな影響を受け、中心部の温度 履歴はセメント水和熱の内部蓄積に大きな影響を受けることによ る。

3）単位セメント量が多いプレキャストコンクリート部材ほど中心部 の履歴最高温度、温度上昇量および温度上昇勾配が大きくなる。 特に、この傾向は早強セメントを用いたプレキャストコンクリー ト部材において顕著である。
参考文献

1)杉山 央, 拁田佳寛, 阿部道彦, 安田正雪ほか: 高强度プレキャストコンク リートの促進養生条件と強度性状（その1，冬期実験の計画および温度履 歴)，日本建築学会大会学術講演梗概集 A, pp. 1089-1090，1993.9

2）白石清隆，桝田佳寛，阿部道彦，杉山 央ほか: 高強度プレキャストコンク リートの促進養生条件と強度性状（その2. 冬期実験における強度性状), 日 本建築学会大会学術講演梗概集 A, pp. 1091-1092，1993.9

3）杉山 央, 拁田佳寛, 阿部道彦，前田弘美ほか: 高強度プレキャストコンク リート製造時の缊度履歴と強度発現性状の関係（その 4. 早強ならびに低発 熱型セメントを用いた模擬部材の温度履歴), 日本建筮学会大会学術講演梗 概集 A，pp. 757-758，1996. 9

4）前田弘美, 桝田佳寛, 阿部道彦, 杉山 央ほか: 高強度プレキャストコンク リート製造時の温度履歴と強度発現性状の関係（その5. 早強ならびに低発 熱型セメントを用いた模擬部材の強度性状), 日本建築学会大会学術講演梗 概集 A，pp. 759-760，1996.9

5）地濃茂雄, 杉山 央: マッシブなコンクリートの強度発現傾向（セメントの 水和熱の蓄積による高温履歷の影響), 日本建築学会構造系論文報告集, 第 436 号, pp. 1-12, 1992.6

6）杉山 央, 桝田佳寛 : 初期高温履歴を受けたコンクリートの長期強度発現 性，日本建築学会構造系論文集，第 515号, pp. 23-30, 1999.1

7) 杉山 央, 拁田佳寛: 早強および低熱ボルトランドセメントを用いたコンク リートの強度発現性に及ぼす初期高温履歴の影響, 日本建築学会構造系論文 集, 第 520 号, pp. 9-16, 1999.6

8) H. Sugiyama, Y. Masuda and M. Abe: Strength Development of Concrete Cured Under High-temperature Conditions at an Early Age, Proceedings of 5th CANMET/ACI International Conference on Durability of Concrete (SPAIN), pp.965-982, 2000.6

9）杉山 央: 高強度マスコンクリートの温度履歴特性と強度発現性, コンク リート工学, Vol. 38, No. 7, pp. 3-9, 2000.7

[2001年 4 月 11 日原稿受理 2001 年 7 月 27日採用決定］ 